\title{
Hypertension awareness and perception: Health Education Implication on prevention and control among rural dwellers, South East Nigeria
}

\author{
Osuala Eunice Ogonna (RN, RM, MPH, PhD). \\ Department of Nursing Science, Nnamdi Azikiwe University, Nnewi Campus, South East, Nigeria
}

\begin{abstract}
Awareness, knowledge and attitude about hypertension have been indicated to influence practice of healthy lifestyle which has implications for hypertension prevention and control. Awareness of predisposing factors of a disease and the people's perception of its seriousness informs their decision on whether or not to adopt preventive measures. This study was designed to assess the effects of a Community Health Nurse-Led Intervention (CHNI) on awareness and perception of residents of Isunjaba, Imo State, Nigeria on hypertension. The study adopted a quasi-experimental design. Multistage cluster sampling technique was used to select two communities in Isunjaba, assigned into Experimental (EG) and Control groups (CG) by balloting. A total of 442 rural dwellers (199 from EG and 243 from CG), between ages 20 and 75 years that consented, were selected. A validated structured questionnaire with Correlation coefficient value of 0.76 was used to assess level of awareness and perception using five and eight statements respectively. The CHNI consisted of instruction on risk factors for BP, consumption of healthy diet, regular BP check and exercise. The CHNI was administered to EG for two weeks. Data were collected at baseline, Post Intervention1 (P1) and post intervention 2 (P2) at three monthly intervals. Descriptive statistics was employed in analysis and results presented using tables. At baseline, $254(61.7 \%)$ were aware of cases of sudden death and stroke in the community. Only 125 (32.9\%) knew their blood pressure reading while 112 (28.7\%) knew they were hypertensive. Myths about hypertension were revealed through their perception. There was marked improvement in awareness and perception in the Experimental group after community health nursing intervention buttressing the importance of Health Education. Community Health Nurses interact with individuals, families and communities at all settings to provide services especially at homes more than any other member of the health team. Regular health information in respect of hypertension, by this group is recommended to curb ignorance among rural dwellers where only a few attain tertiary education.
\end{abstract}

Key words :- Hypertension, Health-education, Rural Dwellers, Nurse-Led intervention, Prevention.

\section{Introduction}

Hypertension is a disease that is both common in urban and rural populace (Jolly, 2010 and Okpechi, et. al., 2013). It is the fastest rising CVD in Africa (Kadiri, 2005; Ike et. al., 2009, and Dalal, et. al., 2011). Over 4.3 million Nigerians, above the age of $15 y e a r s$ are classified as hypertensive with blood pressure greater than $160 / 90 \mathrm{mmHg}$, thus making it the commonest non communicable disease in Nigeria (Familoni and Olunuga, 2005; Awotidebe, et, al., 2014). A study in Nsukka, South- East of Nigeria even reported a prevalence of $40.3 \%$ percent (Ekwunife, et al., 2010). Similarly a study in Port Harcourt, South- South of Nigeria reported a prevalence of $40.8 \%$ (Akpa, Emem-Chioma and Odia, 2008). A systematic review and meta- analysis by Ataklte , et.al., (2014) to assess the recent burden of hypertension in Sub-Saharan Africa, based on 33 surveys pooled from 2000 - 2013 publications involving 110,414 participants of mean age 40years revealed prevalence varied from 15- 70\%. By casual observation cases of stroke and sudden deaths have been noted in Isunjaba in Isu Local Government Area of Imo State by the researcher. These cases may be linked to cardiovascular diseases (CVD). The world being a global village, Isunjaba need to be protected from cardiovascular diseases (CVD). Hypertension if left unchecked especially in the rural area where the population is predominantly that of old people, would increase its incidence, cases of stroke, heart failure, glaucoma and renal failure. A few studies have been done on hypertension among rural dwellers (Ekwunife, et. al., 2010 and Demaio, et. al., 2013) and this is applicable to Isunjaba. If nothing is done, problem of stroke and sudden deaths would continue. There is need for early diagnosis, prevention and control. Information on level of awareness and perception of community members about Hypertension is needed as the basis to guide intervention plan. This informed the decision of the researcher to investigate the awareness and perception of rural dwellers in Isunjaba of Imo State, on hypertension in order to reduce the disease burden through improved awareness and positive perception using a Health Education package. 


\section{Method}

It is a community intervention study that utilized quasi experimental design involving an experimental and a control group. The study was carried out in two communities in Isunjaba. Structured questionnaire was used to elicit information on awareness and perception of hypertension.

Sample size of 442 was determined based on the formula for two proportions (Maxwell, 1998).

$\mathrm{n}=\left[\frac{Z \alpha \sqrt{ } 2 \mathrm{pc}(1-\mathrm{pc})-Z \beta \sqrt{ } \mathrm{pt}(1-\mathrm{pt})+\mathrm{pc}(1-\mathrm{pc})]^{2}}{(\mathrm{pt}-\mathrm{pc})^{2}}\right.$

Sampling procedure

Multistage Cluster sampling

Multistage sampling technique was adopted: Through purposive sampling, out of the 21 Local Government Areas (LGA) in Imo State, Isu LGA and Isunjaba, one of the five towns in Isu LGA were selected. This was followed by simple random selection by balloting, the required number of communities, clusters of villages, households and participants.

\section{Selection of Town}

Isu LGA comprises of five towns, Isunjaba (a rural community) one of the towns was chosen purposively for the study based on researcher's observation and familiarity with health issues in the community.

\section{Selection of communities}

From the four autonomous communities, using simple random (balloting) technique, two communities were selected. One of the communities was assigned head and the other tail by balloting. With tossing of the coin, the first appearance which was the coat of arms (head) was assigned the experimental group, and Isuobishi (subjects) from this process was assigned the Experimental group (Group A) while Isuokporo (control) was assigned the Control group (Group B). The subjects in Isuobishi were therefore assigned into Group A, and those in Isuokporo into Group B, as experimental and control respectively.

\section{Selection of villages}

The eight villages in groups A - Isuobishi were categorized chronologically into two clusters, senior and junior groups. Similarly same was done for the eleven villages in Group B - Isuokporo. Two villages were then randomly selected from each cluster.

\section{Household selection}

In each of the two selected villages in the clusters for the study, households were selected, using odd numbers which was determined by tossing the coin. Head (side with coat of arms) was for even while tail (side with unit of amount) was for odd. Households identified as odd from this exercise were selected until required number was got.

\section{Selection of participants}

A total of 442 subjects were selected for the study as this figure is the highest calculated sample size figure and as such accommodates the other two values. Experimental group constituted a sample of 199 subjects (45\%) while control constituted 243 (55\%), respectively. This was based on proportion of 968:1,184 which makes a total for a study population of 2,152. In each village, the centre was identified. Tossing the coin, based on the side of the coin, (the head is right and the tail is left) the first house on the street was identified, followed by selection of men and women alternatively from the selected households until required number was got. A total of 442 rural dwellers (199 from EG and 243 from CG), between ages 20 and 75 years that consented, were selected. A validated structured questionnaire with Correlation coefficient value of 0.76 was used to assess level of awareness of hypertension and its sequel as well as how it is perceived by community members.

Four teachers were trained on use of research instrument for accuracy and uniformity.

Translation and back translation was done. The questionnaire was developed in English and translated to Igbo (local language) after which two literate indigenes who have a good command of both languages translated the Igbo version back to English. The English version was compared with the original English version for congruency. Coefficient correlation of 0.8 was computed on a test-retest of the instrument Copies of both the English and Igbo versions were administered three times to 10 people in the community (five males and 5 females) in the order of English, Igbo and English. The results were then correlated for equivalence, stability and congruency to ensure that the intended meaning was maintained and value was $0.763,0.763$ and 0.762 respectively. Approval to conduct the study was obtained from the ethical committee, Nnamdi Azikiwe University Teaching Hospital Nnewi, Anambra State in line with its ethical protocol (NAUTH/CS/66/VOL.3/009). Participants were given essential information about the study procedure, duration, its purpose and benefits. Confidentiality of the respondents was assured by not writing names or addresses on the questionnaire. The right and integrity of the study participants was fully protected and written consent also 
obtained from each and every one of them. Only those who were willing to participate were included in the study.

\section{a. Pre-intervention phase (Baseline)}

This involved gathering of data from both experimental and control groups on the various variables using questionnaires. After identifying the first household and participant for the study in his or her home, (at first contact purpose of study was explained and written informed consent obtained). Data was collected with the assistance of the four trained teacher - research assistants for this purpose. The exercise ran for four weeks at baseline. Each of the two communities chose two days in a week, with their market day excluded. This exercise was repeated twice at three monthly intervals in both experimental and control groups.

\section{b. Intervention}

There was a Community Health Nursing intervention for group A, (Experimental) and none for Group $\mathrm{B}$, (Control) at the intervention stage. This was to improve level of awareness, positive perception of subjects in relation to hypertension prevention and control through health education. This was done two weeks after the baseline questionnaires administration was over at the chosen hall at Eze's (Ruler) palace and village hall for their convenience. The interaction took place in four sessions over the two weeks which was again based on their convenience. A session was between 37 and 42 participants. There were four modules and two were taught in a day and the other two on the following day for each group of the 37 - 42 participants. There were morning and evening sessions. Review of previous lecture always preceded the next one.

\section{c. Post Intervention}

The questionnaires were distributed again at three months to both group A (Experimental) and B (Control). Blood pressure and anthropometric measurements (height and weight) were also taken. A repeat of this exercise was carried out in another three months to assess sustainability.

Data analysis was done by coding and scoring of items on the questionnaire. Awareness and perception scores were computed based on the responses; each correct response has a score of 1 , incorrect response was scored 0 and 'do not know' was not scored. The resulting scores were converted to percentages, therefore the resulting scores ranged from $(0-100 \%)$. The scores were categorized as follows: $70-100 \%$ (high), $50-69 \%$ (average) and $0-49 \%$ (low). Inferential statistics was done using $X^{2}$ at $\mathrm{p}$ value $0.000<0.05$. The percentage and frequency of socio-demographic characteristics was presented in tables and figures; age range and mean age was reported in statement format. Grouping of sex under experimental and control was presented in diagram.

\section{Results}

Demographic variable showed that ages of respondents ranged from $20-75$ with mean $49.49 \pm 14.45$. Ages $50-59$ were greatest in number $100(22.6 \%)$ followed by ages $60-69$ [94 (21.3\%)] while < 30 were the least with $42(9.5 \%)$ in number. Participants with primary school education had the highest percentage of 38.5 . Participants of low income class were $243(57.6 \%)$ while upper class was $28(6.6 \%)$. This is based on house hold income/ day of Lower class $<$ N $500(<\$ 3)$, Middle class N $500-2500(\$ 3-15)$, and Upper class $>$ N 2500 (> \$15) (United States Census Bureau household income, 2006). (Table 1) There were more women in the study than men (Fig 1) which showcased a typical rural community in Nigeria.

Respondents' awareness on hypertension pre and post intervention was documented. At baseline, out of the 442 participants, $403(92.6 \%)$ have heard of hypertension, $112(28.7 \%)$ knew they have hypertension, 125 (32.9\%) knew their blood pressure reading while $254(61.7 \%)$ were aware of cases of sudden death and stroke in the community. Out of these figures, 179 (90.4\%) of the experimental group have heard of hypertension, 56 (28.6\%) knew they have hypertension, $56(28.6 \%)$ knew their blood pressure reading and $108(56.5 \%)$ were aware of incidents of stroke and sudden death while in the control group it was 224 (94.5\%), 59 (28.1\%), 69 $(37.5 \%)$ and $146(66.1 \%)$ respectively. At end - line in the experimental group, $199(100.0 \%)$ have heard of hypertension, 76 (34.7\%) knew they have hypertension,198 (99.5\%) knew their blood pressure reading and195 $(98.0 \%)$ were aware of incidents of stroke and sudden death in their community while in the control group it was $235(97.5 \%), 76(34.7 \%), 104(52.0 \%)$ and $153(68.9 \%)$ respectively (Table 2).

Respondents' perception of hypertension in Experimental and Control groups pre and post intervention revealed myths about hypertension were revealed through their perception. Out of the 442 participants, 397 (95.2\%) stated that much thinking is main cause of hypertension.168 (54.8\%) stated that hypertension results from knock on the head by spirits, 209 (62.8\%) stated that hypertension and stroke is sent by enemy through 'juju'. Responses as Hypertension is detected on sight and is curable was $183(46.4 \%)$ and $186(55.0 \%)$ respectively. The misconceptions were reduced in the experimental group at end - line of intervention e.g. hypertension is sent by enemy through juju reduced from $96(61.5 \%)$ to 7 (3.5\%) and $1(0.8 \%)$ 
at midterm and end-line respectively (Table 3 ). The $p$-value of $0.000<0.05$ showed that there was a significant relationship between level of education and perception of hypertension.

\section{Discussion}

High awareness and negative perception was same with the studies by Ekwunife (2010) and Osuala, Oluwatosin, and Kadiri (2014). Even in the Western part of the country, myths about cancer which is also a non communicable disease was recorded by Adedemeji, Lounsbury, Popoola, Asuzu, Lawal, Oladoyin, et al. in their study in Ibadan. This may be common with rural dwellers where the population constitutes mainly of non educated elderly people and children.

\section{Conclusion}

The influence of health education can not be over emphasized as revealed in the post intervention outcome in the experimental group. There was also significant relationship between level of education of respondents and their perception. Community Health Nurses should therefore scale up Health Education programmes to correct myths of hypertension while education to Secondary School level (Higher School) and Adult Education should be made compulsory by the Government.

\section{References}

[1] Jolly, S. 2010. Higher Cardiovascular disease prevalence and mortality among younger blacks compared to whites. Am J Med 9: 811-8.

[2] Okpechi, I. G., Chukwuonye, I. I., Toffin, N., Madukwe, O. O., Onyeonoro, U. U., Umeizudike, T. I., and Ogah O, S. 2013. Blood pressure gradients and cardiovascular risk factors in urban and rural populations in South East Nigeria using WHO STEPwise approach.PLoS 8; 9:e73403

[3] Kadiri, S. 2005. Tackling cardiovascular diseases in Africa. BJM [West African Edition, 8.]331:771 -772.

[4] Ike, S. O, Aniebue, P. N. and Aniebue, U. U. 2010. Knowledge, perception and practices of lifestyle - modification measures among adult hypertensive in Nigeria. Royal Society of Tropical Medicine and Hygiene 104; 1: $55-60$.

[5] Dalal, S., Beunza, J. J., Volmink, J., Adebamowo, C., Bajunirwe, F., Njelekela, M., Holmes, M. D. 2011. Non-communicable diseases in sub-Saharan Africa: what we know now. International Journal of Epidemiology, 40;4: 885-901. doi:10.1093/ije/dyr050

[6] Familoni, O. B.and Olunga, T. O. 2005. Comparison in the knowledge and awareness of hypertension among hospital and factory workers in Sagamu, Nigeria. Nigerian Medical Practitioner, 47.3: 43-45.

[7] Awotidebe, T., Adedoyin, R., Rasaq, W., Adeyeye, V., Mbada, C., Akinola, O., \& Otwombe, K. (2014). Knowledge, attitude and Practice of Exercise for blood pressure control: A cross-sectional survey, 10(1), 1. Retrieved 10 Dec. 2014 fromhttp://search. informit.com. au/ documentSummary; dn=755688598487763;res=IELHEA

[8] Ekwunife, O. I., Udeogaranya, P. O and Nwatu, I. L. (2010). Prevalence, awareness, treatment and control of hypertension in a Nigerian population. Health 2, 7:731-735.

[9] Akpa,M. R., Emem-Chioma, P. C. and Odia, O. J. 2008. Current epidemiology of hypertension in Port Harcourt metropolis, Rivers State, Nigeria. Port Harcourt Medical Journal 2:218-223.

[10] Ataklte, F., Erquo, S., Kaptoge, S., Taye, B., Echouffe - Tcheugu, J. and Kengne, A.P. 2014. Burden of undiagnosed hypertension in Sub-Saharan Africa: A systematic Review and Meta - Analysis. Hypertensionaha.11.10:114.04394 doi:101161/hypertensionaha114.04394

[11] Demaio, A. R.,Otgontuya, D., Maximillam de Courten., Bygbjerg Ib C., Enkhtuya P., Meyerowitsch, D. W. and Oyunbileg, J. 2013. Hypertension and hypertension- related disease in Mongolia; findings of a national knowledge, attitude s and practice study. BMC Public Health. 13: 194.

[12] Maxwell, F. P. 1998. A-Z of Medical statistics. A comparism for critical appraisal. London, Oxford University Press Inc. New York.

[13] United States Census Bureau, household income 2006. Classification of income was adopted from USA bureau of household income.

[14] Osuala, EO. Oluwatosin, OA. \& Kadiri, S. Knowledge, attitude to hypertension and lifestyle habits of rural dwellers in Owerre Nkwoji, Imo State, Nigeria. Journal of Public Health and Epidemiology 6 (1) Jan. 2014. pp $48-51$.

[15] Adedemeji, A.A., Lounsbury, D., Popoola, O., Asuzu, C., Lawal, A., Oladoyin, V., Crifase,C. Agalliu, I., Shankar, V. and Adebiyi, A. (2016) Improving Outcomes in Cancer Diagnosis,Prevention and Control: Barriers, Facilitators and the Need for Health Literacy in IbadanNigeria. Psycho oncology, 5, 24.

Table 1: Socio demographic characteristics of respondents in Experimental and Control

\begin{tabular}{|c|c|c|c|c|c|c|}
\hline Variables & $\begin{array}{l}\text { Experimental } \\
N=199\end{array}$ & \multicolumn{2}{|c|}{$\begin{array}{l}\text { Control } \\
N=243\end{array}$} & $\begin{array}{l}\text { Total } \\
\mathrm{N}=442\end{array}$ & $\mathrm{X}^{2}$ & P value \\
\hline \multicolumn{2}{|l|}{ Sex } & \multirow[b]{2}{*}{108} & \multirow[b]{2}{*}{ (44.4) } & & & \\
\hline Male & 74 (37.2) & & & $182(41.2)$ & 0.123 & 2.380 \\
\hline Female & $125(62.8)$ & \multicolumn{2}{|c|}{$135(55.6)$} & $260(58.8)$ & & \\
\hline Marital Status & & & & & 0.365 & 0.947 \\
\hline Married & $166(83.4)$ & \multicolumn{2}{|c|}{198 (81.5) } & $364(82.4)$ & & \\
\hline Single & $22(11.1)$ & \multicolumn{2}{|c|}{$31(12.8)$} & $53(12.0)$ & & \\
\hline Separated & $2(1.0)$ & \multicolumn{2}{|c|}{$3(1.2)$} & $5(1.1)$ & & \\
\hline Widowed & $9(4.5)$ & \multicolumn{2}{|c|}{$11(4.5)$} & $20(4.5)$ & & \\
\hline
\end{tabular}




\begin{tabular}{|l|l|l|l|l|l|}
\hline Age (Yrs) & & & & 1.280 & 0.937 \\
\hline$<30$ & $21(10.6)$ & $21(8.6)$ & $42(9.5)$ & & \\
\hline $30-39$ & & & & & \\
\hline $40-49$ & $30(15.1)$ & $37(15.2)$ & $67(15.2)$ & & \\
& & $47(19.3)$ & $90(20.4)$ & & \\
\hline $50-59$ & $45(22.6)$ & $55(22.6)$ & $100(22.6)$ & & \\
\hline $60-69$ & $40(20.1)$ & $54(22.2)$ & $94(21.3)$ & & \\
\hline$>70$ & & & & & \\
\hline Occupation & $20(10.1)$ & $29(11.9)$ & $49(11.1)$ & & \\
\hline Jobless & $21(10.6)$ & & & 9.197 & 0.056 \\
\hline Civil Servant & $45(22.6)$ & $28(11.5)$ & $49(11.1)$ & & \\
\hline Farming & $68(34.2)$ & $114(46.9)$ & $182(41.2)$ & & \\
\hline Petty trading & $37(18.6)$ & $32(13.2)$ & $69(15.6)$ & & \\
\hline Artisan & $28(14.1)$ & $30(12.3)$ & $58(13.1)$ & & \\
\hline Income & & & & 13.988 & 0.003 \\
\hline Upper class & $14(7.0)$ & $14(6.3)$ & $28(6.6)$ & & \\
\hline Middle class & $31(15.6)$ & $11(26.2)$ & $42(10.0)$ & & \\
\hline Lower middle class & $50(25.1)$ & $59(26.5)$ & $109(25.8)$ & & \\
\hline Lower class & $104(52.3)$ & $139(62.3)$ & $243(57.6)$ & & \\
\hline Religion & & & & 7.077 & 0.132 \\
\hline Anglican & $11(5.5)$ & $9(3.7)$ & $20(4.5)$ & & \\
\hline Catholic & $147(73.9)$ & $200(82.6)$ & $347(78.7)$ & & \\
\hline Pentecostal & $33(16.6)$ & $26(10.7)$ & $59(13.4)$ & & \\
\hline Moslem & $2(1.0)$ & $0(0.0)$ & $2(0.5)$ & & \\
\hline African Traditional & $6(3.0)$ & $7(2.9)$ & $13(2.9)$ & & \\
\hline Level of education & & & & 1.655 & 0.647 \\
\hline Non formal & $29(14.6)$ & $42(17.3)$ & $71(16.1)$ & & \\
\hline Primary & $73(36.7)$ & $97(39.9)$ & $170(38.5)$ & & \\
\hline Secondary & $47(23.6)$ & $51(21.0)$ & $98(22.2)$ & & \\
\hline Tertiary & $50(25.1)$ & $53(21.8)$ & $103(23.3)$ & & \\
\hline & & & & & \\
\hline & & & & & \\
\hline & & & & \\
\hline & & & & \\
\hline & & & & \\
\hline & & & & \\
\hline & & & & \\
\hline & & & & \\
\hline
\end{tabular}



Fig 1: Sex distribution of participants in Experimental and Control.

Table 2: Respondents' awareness of hypertension, pre and post intervention

\begin{tabular}{|c|c|c|c|c|c|c|c|c|c|}
\hline & \multicolumn{3}{|c|}{ Baseline } & \multicolumn{3}{|c|}{ Midterm } & \multicolumn{3}{|c|}{ End-line } \\
\hline Statement & $\begin{array}{l}\text { Exp } \\
\text { Freq } \\
(\%)\end{array}$ & $\begin{array}{l}\text { Contr } \\
\text { ol } \\
\text { Freq } \\
(\%) \\
\end{array}$ & Total & $\begin{array}{l}\text { Exp } \\
\text { Freq } \\
(\%)\end{array}$ & $\begin{array}{l}\text { Contro } \\
\text { l } \\
\text { Freq } \\
(\%) \\
\end{array}$ & Total & $\begin{array}{l}\text { Exp } \\
\text { Freq } \\
(\%)\end{array}$ & $\begin{array}{l}\text { Contro } \\
\text { l } \\
\text { Freq } \\
(\%) \\
\end{array}$ & Total \\
\hline Have heard of hypertension & $\begin{array}{l}179 \\
(90.4)\end{array}$ & $\begin{array}{l}224 \\
(94.5)\end{array}$ & $\begin{array}{l}403 \\
(92.6) \\
\end{array}$ & $\begin{array}{l}198 \\
(99.5) \\
\end{array}$ & $\begin{array}{c}232 \\
(96.7) \\
\end{array}$ & $\begin{array}{l}430 \\
(97.9) \\
\end{array}$ & $\begin{array}{l}199 \\
(100.0)\end{array}$ & $\begin{array}{l}235 \\
(97.5) \\
\end{array}$ & $\begin{array}{l}434 \\
(98.6)\end{array}$ \\
\hline $\begin{array}{l}\text { Have history of } \\
\text { hypertension in your family }\end{array}$ & $\begin{array}{l}65 \\
(35.5) \\
\end{array}$ & $\begin{array}{l}89 \\
(41.8)\end{array}$ & $\begin{array}{l}154 \\
(38.9) \\
\end{array}$ & $\begin{array}{l}77 \\
(39.3) \\
\end{array}$ & $\begin{array}{l}96 \\
(42.1) \\
\end{array}$ & $\begin{array}{l}173 \\
(40.8)\end{array}$ & $\begin{array}{l}81 \\
(40.9) \\
\end{array}$ & $\begin{array}{l}96 \\
(42.1) \\
\end{array}$ & $\begin{array}{l}117 \\
(41.5)\end{array}$ \\
\hline Have high blood pressure & $\begin{array}{l}53 \\
(29.4)\end{array}$ & $\begin{array}{l}59 \\
(28.1)\end{array}$ & $\begin{array}{l}112 \\
(28.7)\end{array}$ & $\begin{array}{c}68 \\
(34.2)\end{array}$ & $\begin{array}{l}75 \\
(34.6)\end{array}$ & $\begin{array}{l}143 \\
(34.4)\end{array}$ & $\begin{array}{l}71 \\
(35.7)\end{array}$ & $\begin{array}{l}76 \\
(34.7)\end{array}$ & $\begin{array}{l}147 \\
(32.2)\end{array}$ \\
\hline $\begin{array}{l}\text { Know your blood pressure } \\
\text { reading }\end{array}$ & $\begin{array}{l}56 \\
(28.6) \\
\end{array}$ & $\begin{array}{l}69 \\
(37.5) \\
\end{array}$ & $\begin{array}{l}125 \\
(32.9) \\
\end{array}$ & $\begin{array}{l}179 \\
(89.9)\end{array}$ & $\begin{array}{l}102 \\
(55.1)\end{array}$ & $\begin{array}{l}281 \\
(73.2) \\
\end{array}$ & $\begin{array}{l}198 \\
(99.5) \\
\end{array}$ & $\begin{array}{l}104 \\
(52.0) \\
\end{array}$ & $\begin{array}{l}302 \\
(75.7) \\
\end{array}$ \\
\hline $\begin{array}{l}\text { Have been incident of } \\
\text { sudden deaths and stroke }\end{array}$ & $\begin{array}{l}108 \\
(56.5) \\
\end{array}$ & $\begin{array}{l}146 \\
(66.1) \\
\end{array}$ & $\begin{array}{l}254 \\
(61.7) \\
\end{array}$ & $\begin{array}{c}171 \\
(86.4) \\
\end{array}$ & $\begin{array}{l}150 \\
(68.5) \\
\end{array}$ & $\begin{array}{l}321 \\
(77.0) \\
\end{array}$ & $\begin{array}{l}195 \\
(98.0) \\
\end{array}$ & $\begin{array}{l}153 \\
(68.9) \\
\end{array}$ & $\begin{array}{l}348 \\
(82.7) \\
\end{array}$ \\
\hline
\end{tabular}


Table 3: Respondents' perception of hypertension in Experimental and Control groups pre and post

\begin{tabular}{|c|c|c|c|c|c|c|c|c|c|}
\hline $\begin{array}{l}\text { Cause of hypertension is } \\
\text { known }\end{array}$ & $\begin{array}{l}103 \\
(72.5)\end{array}$ & $\begin{array}{l}108 \\
(65.9)\end{array}$ & $\begin{array}{l}211 \\
(69.0)\end{array}$ & $\begin{array}{l}49 \\
(26.8)\end{array}$ & $\begin{array}{l}131 \\
(74.0)\end{array}$ & $\begin{array}{l}180 \\
(50.0)\end{array}$ & $\begin{array}{l}17 \\
(8.6)\end{array}$ & $\begin{array}{l}135 \\
(73.0)\end{array}$ & $\begin{array}{l}152 \\
(39.7)\end{array}$ \\
\hline $\begin{array}{l}\text { Much thinking is main } \\
\text { cause of HBP }\end{array}$ & $\begin{array}{l}178 \\
(95.2)\end{array}$ & $\begin{array}{l}219 \\
(95.2)\end{array}$ & $\begin{array}{l}397 \\
(95.2)\end{array}$ & $\begin{array}{l}99 \\
(52.4)\end{array}$ & $\begin{array}{l}230 \\
(97.5)\end{array}$ & $\begin{array}{l}327 \\
(77.4)\end{array}$ & $\begin{array}{l}48 \\
(24.2)\end{array}$ & $\begin{array}{l}233 \\
(97.5)\end{array}$ & $\begin{array}{l}281 \\
(64.3)\end{array}$ \\
\hline $\begin{array}{l}\text { Stroke can result from } \\
\text { knock on the head by } \\
\text { spirits }\end{array}$ & $\begin{array}{l}77 \\
(54.6)\end{array}$ & $\begin{array}{l}91 \\
(54.8)\end{array}$ & $\begin{array}{l}168 \\
(54.7)\end{array}$ & $\begin{array}{l}4 \\
(2.0)\end{array}$ & $\begin{array}{l}106 \\
(61.6)\end{array}$ & $\begin{array}{l}110 \\
(29.7)\end{array}$ & $\begin{array}{l}3 \\
(1.5)\end{array}$ & $\begin{array}{l}108 \\
(62.1)\end{array}$ & $\begin{array}{l}111 \\
(29.8)\end{array}$ \\
\hline $\begin{array}{l}\text { HBP can be detected on } \\
\text { sight }\end{array}$ & $\begin{array}{l}57 \\
(37.5)\end{array}$ & $\begin{array}{l}106 \\
(53.3)\end{array}$ & $\begin{array}{l}183 \\
(46.4)\end{array}$ & $\begin{array}{l}34 \\
(15.1)\end{array}$ & $\begin{array}{l}191 \\
(83.0)\end{array}$ & $\begin{array}{l}225 \\
(52.4)\end{array}$ & $(2.5)$ & $\begin{array}{l}197 \\
(85.30\end{array}$ & $\begin{array}{l}202 \\
(47.0)\end{array}$ \\
\hline $\begin{array}{l}\text { Hypertension can be } \\
\text { diagnosed by any health } \\
\text { worker }\end{array}$ & $\begin{array}{l}146 \\
(78.9)\end{array}$ & $\begin{array}{l}182 \\
(83.1)\end{array}$ & $\begin{array}{l}328 \\
(81.2)\end{array}$ & $\begin{array}{l}99 \\
(49.7)\end{array}$ & $\begin{array}{l}211 \\
(91.7)\end{array}$ & $\begin{array}{l}310 \\
(72.3)\end{array}$ & $\begin{array}{l}56 \\
(28.1)\end{array}$ & $\begin{array}{l}219 \\
(94.0)\end{array}$ & $\begin{array}{l}275 \\
(63.7)\end{array}$ \\
\hline $\begin{array}{l}\text { Hypertension can be } \\
\text { cured once and for all }\end{array}$ & $\begin{array}{l}83 \\
(51.9) \\
\end{array}$ & $\begin{array}{l}103 \\
(57.9)\end{array}$ & $\begin{array}{l}186 \\
(55.0)\end{array}$ & $\begin{array}{l}68 \\
(34.9)\end{array}$ & $\begin{array}{l}175 \\
(87.1)\end{array}$ & $\begin{array}{l}243 \\
(61.4) \\
\end{array}$ & $\begin{array}{l}27 \\
(13.6)\end{array}$ & $\begin{array}{l}189 \\
(52.8)\end{array}$ & $\begin{array}{l}216 \\
(52.8)\end{array}$ \\
\hline
\end{tabular}

